which has been found typical for uncomplicated major surgery. The phosphorus diuresis is a consistent finding and is usually observed to occur in association with retention of calcium.

Small doses of calcium -45 (14 $\mu \mathrm{c}$.) and phosphorus -32 $(20$ uc.) have been administered parenterally to patients $48 \mathrm{hr}$. before surgery and the specific activity of the urinary calcium and phosphorus plotted against time ${ }^{2}$. In three out of eight patients studied, marked deviations from the expected calcium specific activity curve have been observed in the $48 \mathrm{hr}$. following operation (Fig. 2A). Two out of two phosphorus specific activity curves have shown a similar effect of operation (Fig. $2 B$ ).

It is suggested that the above observations are consistent with a post-operative calcium mobilization which, in most cases, could be associated with an increase in parathyroid activity. It could follow that surgical trauma produces a condition where there is a local or systemic demand by the tissues for calcium. This possibility, and the further speculation that changes in the calcium concentration of tissues may favour the spread and establishment of metastases, are at present being investigated.

We are indebted to the medical and nursing staff of the Special Unit for their generous co-operation.

K. W. StarR

K. N. WYNNE

S. H. Chorlton

Special Unit for Investigation and Treatment,

New South Wales State Cancer Council, Randwick, New South Wales. Aug. 20.

'Coman, D. R., Science, 105, 347 (1947). - Bronner, F., Harris, R. S., Maletskos, (. J., and Benda, C. K., J.
(lin. Invest., 35, $78(1956)$.

\section{Changes in the Sensitivity of Enzymes in the Dry State to Radiation}

THere is now considerable evidence that the sensitivity to radiation of enzymes in the dry state is influenced by the medium in which the enzymes are dried.

It was first noticed that different, commercially available invertase preparations had different radiation cross-sections in the dry state in a vacuum. This observation led us to prepare invertase solutions from commercial yeast using the purification methods described by Dieu ${ }^{1}$, Fisher and Kohtes ${ }^{2}$, and Sumner and $\mathrm{O}^{\prime} \mathrm{Kane}^{3}$. Although the enzyme solutions were prepared from the same yeast, the sensitivity of the enzyme showed variations even at different stages of purification. In Table 1 some of these results are given.

It can be seen that on dialysis of the Dieu extract the sensitivity of the enzyme increases considerably. If the dialysate from the dialysed extract of the Dieu preparation is added again to the residue, the cross-section returns to that of the crude extract. After free $\mathrm{SH}$ groups had been shown to be present in the yeast extract, cysteine and glutathione were

Table 1. Inactivation Cross-ShCtion $\left(\right.$ A. $^{2}$ ) OF DRY Yeast Invartase. $40 \mathrm{MeV}$. $\alpha$-particles. Cross-section in yeast cell, $2,000 \mathrm{A.} .^{2}$

\begin{tabular}{|l|l|l|l|}
\hline Purification method & \multicolumn{1}{|c|}{ Dieu } & Sumner & \multicolumn{1}{c|}{ Fisher } \\
\hline Crude extract & $1,350 \pm 50$ & $1,400 \pm 100$ & $2,400 \pm 100$ \\
Dialysed extract & 2,500 & & 2,300 \\
Precipitation & 3,200 & 2,550 & 1,900 \\
Final product & & 3,800 \\
\hline
\end{tabular}

Table 2. Recative Radiation Sensitivities of Enzymes in The DRY STATE

\begin{tabular}{|c|c|c|c|c|}
\hline Additive & Invertase & Ribonuclease & Papain & Urease \\
\hline Pure & $1 \cdot 0$ & $1 \cdot 0$ & $1 \cdot 0$ & $1 \cdot 0$ \\
\hline Cysteine & $0 \cdot 5$ & 一 & — & $0.5-0 \cdot 7$ \\
\hline $\begin{array}{l}\text { Glutathione } \\
\text { Yeast extract }\end{array}$ & $\begin{array}{l}0.5 \\
0.45\end{array}$ & $\begin{array}{l}0.52 \pm 0.10 \\
0.52 \pm 0.10\end{array}$ & $0.6-0.8$ & 0.8 \\
\hline $\begin{array}{l}\text { Yeast extract } \\
\text { Ribonucleic acid }\end{array}$ & 0.45 & $\begin{array}{l}0.52 \pm 0.10 \\
0.41 \pm 0.07\end{array}$ & & \\
\hline Acetate buffer & $1 \cdot 4-1 \cdot 6$ & $4.8 \pm 1.4$ & & \\
\hline $\begin{array}{l}\text { Sucrose } \\
\text { Sodium chloride }\end{array}$ & $1 \cdot 5-3 \cdot 5$ & $\begin{array}{l}2 \cdot 6 \pm 0.5 \\
0.98 \pm 0.21\end{array}$ & & \\
\hline
\end{tabular}

tested for protective ability and were found to decrease the cross-section of several enzymes. Drying the enzyme from acetate buffer or from salt solutions in some cases led to greater sensitivity to radioactivity. In Table 2 the relative radiation sensitivities (for 4-MeV. deuterons) of four different enzymes dried down in solutions of various compounds are listed. In general, the effect of a compound on the radiosensitivity varied with its concentration. The results in Table 2 were obtained with a quantity of the added compound approximately one to ten times that of the enzyme used. Increasing the amount of compound added did not appear to change the values in Table 2 very much.

The conclusion to be drawn from these results is that the effect of ionizing radiation can either be increased or decreased. Reduction in radiation sensitivity of dry materials by added substances has recently been reported by Norman and Ginoza for catalase $^{4}$ and ribonucleic acid ${ }^{5}$ and has been frequently observed in radiation studies on high polymers ${ }^{6}$.

Further details will be reported elsewhere. This work was supported by a contract from the U.S. Atomic Energy Commission.

\section{REINIER BraAMS* Franklin Hutchinson DILIP RAY}

Department of Biophysics, Yale University,

New Haven, Conn. Sept. 16.

* Present address : Department of Medical Physics, Bijlhouwerstraat 6 , Utrecht.

${ }^{1}$ Dieu, H., Bull. Soc. Chim. Belg., 55, 306 (1946).

${ }^{2}$ Fisher, Ed. H., and Kohtes, L., Helv. Chim. Acta, 34, 1123 (1951). ${ }^{3}$ Sumner, J. B., and O'Kane, D. J., Enzymologia, 12, 251 (1948).

${ }^{4}$ Norman, A., and Ginoza, W., Radiation Res., 9, 77 (1958).

Norman, A., and Ginoza, W., Nature, 179, 520 (1957).

"Alexander, P., and Charlesby, A., Nature, 173, 578 (1954).

\section{Radioprotective Action of 5-Hydroxy- tryptamine}

Tryptamine and its hydroxyl derivative are powerful radioprotective amines in vivo ${ }^{1,2}$, but they also give rise to physiological changes. Bacq and Alexander ${ }^{3}$ state that tryptamine is not a vasoconstrictor, but is nevertheless as good a radiation protector of mice as 5-hydroxytryptamine. However. tryptamine causes intense smooth muscle contraction, similar to its hydroxyl derivative ${ }^{4,5}$. While this pharmacological activity for tryptamine is much less, molecule for molecule ${ }^{6}$, our studies indicate this also applies to its radioprotective properties in rats.

Both amines protect polymer irradiated in oxygenated solution in vitro ${ }^{2}$, and Bacq and Alexander regard the protective action in vivo as one of competition for radicals (particularly $\mathrm{HO}_{2}^{-}$) from radiolysis of water. Others ${ }^{4}$ have suggested that protection in vivo may be due to an 'oxygen effect'. 